\title{
Considerações acerca da violência na cena
}

\section{Considerations about violence in the theatrical scene}

\section{Maria Tendlau}

Maria Tendlau

Doutoranda no PPG em Artes Cênicas da ECA-USP

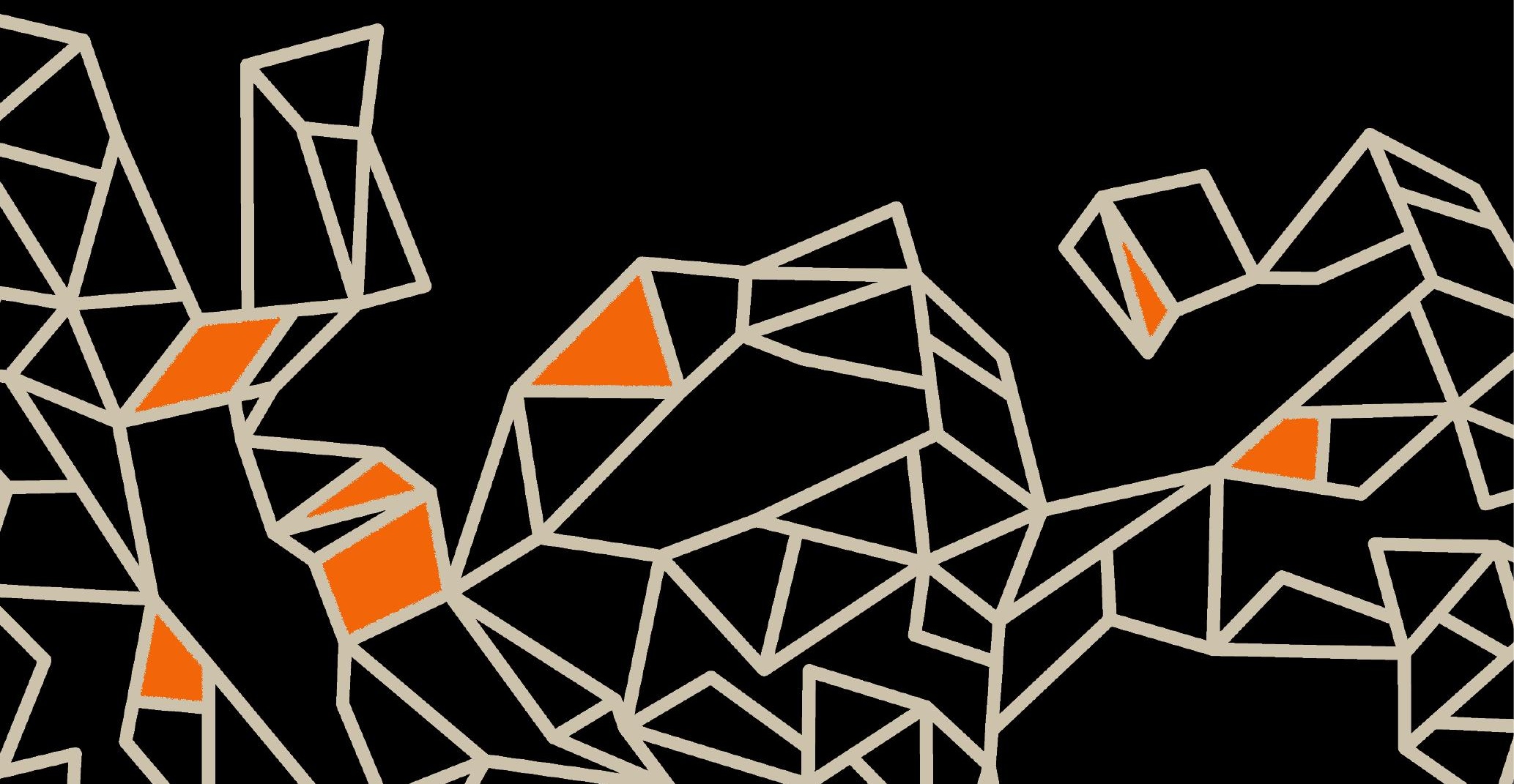




\section{Resumo}

O artigo examina alguns aspectos da representação/presentificação, partindo da abordagem teórica de Erika Fischer-Lichte, acerca dos tensionamentos entre realidade e ficção na cena contemporânea, da ideia de teatro expandido proposta por lleana Dieguez, e da reflexão sobre a teatralidade e o espetáculo de Helga Finter. Esses aspectos guiam a mirada de dois exemplos no trabalho do Coletivo Bruto: a encenação $O$ que está aqui é o que sobrou, obra criada pelo coletivo a partir do Material Fatzer de Brecht e Muller, e a encenação de Vergonha, de autoria própria do coletivo, para refletir sobre a representação da violência na cena.

Palavras-chave: Espectador, Realidade, Ficção, Violência, Coletivo Bruto.

\section{Abstract}

The article examines some aspects of representation/presentification, based on the theoretical approach by Erika Fischer-Lichte, about the tensions between reality and fiction in the contemporary scene, the idea of expanded theater proposed by lleana Dieguez, and the reflection on the theatricality and the spectacle by Helga Finter. These aspects guide the view of two examples in the work of the Coletivo Bruto: the staging of What's here is what's left, a work created by the collective from Brecht and Muller's Material Fatzer, and the staging of Shame, authored by the collective, to reflect on the representation of violence in scene.

Keywords: Spectator, Reality, Fiction, Violence, Coletivo Bruto.

O Coletivo Bruto surgiu, em 2007, pela reunião de artistas de diferentes e múltiplas formações com o interesse de formar um grupo de criação que trabaIhasse pelo hibridismo e pelo diálogo entre linguagens, na composição de obras artísticas. O objetivo, nas palavras que figuram no perfil do blog do Coletivo, era dedicar-se à criação de matérias poéticas em diálogo com demandas contemporâneas, utilizando certa perversidade de imagens e discursos. Visavam à presença das estereotipias e dos fetiches nas aglomerações urbanas, assim como refletir sobre os entraves da representação, na busca de um entendimento mais amplo das dinâmicas que sustentam a vida coletiva e a sobrevivência. 
O texto do autor alemão Armin Petras, Guerra cega simplex feche os olhos e voe ou guerra malvada, foi o suporte escolhido para o primeiro trabalho do coletivo. Assinado pelo pseudônimo de Petras, Fritz Kater, e pela bailarina cega Pernille Sonne, o texto possui uma escritura mülleriana ${ }^{1}$ que aborda a ideia de guerra total. Em Guerra cega, Kater articula o pensamento kantiano em contraponto à teoria marxista, claramente se inspirando no livro Multidão, de Michael Hardt e Antonio Negri (2005). Seu foco é a capacidade/necessidade de sobrevivência diante do quadro geral de assédio, seja na guerra tradicional (concreta, com batalha de campo e inimigo declarado), seja na guerra difusa e globalizada (na qual os resultados de disputas desterritorializadas são sentidos em lugares distintos, por degradação do meio ambiente, por demandas das sociabilidades contemporâneas pautadas pelas leis de mercado, entre outros efeitos). A dramaturgia de Kater questiona o estado de guerra como um estado perene que mantém em equilíbrio a ordem mundial capitalista. $\mathrm{Na}$ conjunção de diversas narrativas, a metáfora de cegueira e da guerra vai sendo tecida por fragmentos díspares que atuam por colisões sucessivas, como numa discotecagem. Feche os olhos e voe. Assim a cegueira divide-se entre a inviabilidade do conhecimento, imposto pela lógica de mercado, e a possibilidade de uma fantasia libertária nas novas representações sensíveis.

na guerra regional bem como na luta privada existencial é possível viabilizar as chances de sobrevivência nas lutas em andamento de maneira modificada através de acúmulo de técnicas de percepção sensual e ampliação do racional/ nas guerras dos séculos 20 e 21 cada vez mais globais e envolvendo cada vez mais setores toda a técnica de treinamentos sensuais e racionais para a superação dessas crises está sendo cada vez menos promissora de sucesso/ porque essas guerras não só visam o aniquilamento do indivíduo e a consequente maximização do lucro sempre para outro como também inevitavelmente destroem o equilíbrio cultural e social global de maneira irreversível e com isso também climático aniquilam as condições de vida do agredido bem como do agressor ou o abalam de maneira essencial e irreversível/ [...]

por 10.000 anos o sistema de aumento de produtividade funcionou através das guerras agora chegamos ao limite dessa ideia/ se agora o homem quiser continuar se desenvolvendo ou talvez só sobreviver isso só será possível numa situação de entendimento/ o estado de paz entre os

1 Armin Petras considera Heiner Muller seu mestre, e isso está presente todo tempo em sua escrita, seja por citações diretas, seja pelo estilo. 
homens que convivem lado a lado não é um estado natural, sendo este muito mais um estado de guerra - portando precisa ser instituído/ uma vez que entre as excessivas comunidades dos povos da terra chegou-se a esse ponto, que infringir a lei em determinado lugar da terra é sentido por todos: a ideia de um direito do cidadão do mundo não é uma forma de impressão fantástica ou exagerada da lei, é sim a ampliação necessária dela de encontro à paz eterna, a qual só podemos adular se for para ficarmos em proximidade contínua. (KATER; SONNE, 2004, p. 9)

Recupero aqui o texto de Petras porque ele pautará o Coletivo Bruto, desde sua origem, a investigação sobre a guerra total e o enfrentamento do desafio das representações/presentificações da violência na cena. E é sobre a conformação dessa violência que me debruço neste momento.

\section{Realidade e ficção, presença e narrativa}

Erika Fischer-Lichte (2013) caracteriza a tensão entre o real e o ficcional como constitutiva do fenômeno teatral. É no confronto entre uma representação e uma copresença real entre atores e espectadores que se estabelece o espaço da cena segundo a autora. Por toda a história do teatro, como bem explicita Fischer-Lichte, a dialética entre o corpo real, fenomenal do ator e a evocação/ incorporação da personagem ficcional sobre aquele corpo, corpo semiótico, produzirá diferentes sínteses em diferentes momentos históricos. Essa tensão poderia ser ampliada para a própria espacialidade da cena, num momento em que a ideia de site specific se tornou usual no teatro. Ou seja, espaço real em confronto com espaço ficcional. Mimese e diegese, e suas articulações, donde o espaço ficcional se amplia para fora da cena, mas o espaço real, mesmo ativado pela mimese (que pretende a ficção), lastreia o lugar do aqui-agora. Assim, uma sobreposição de narrativas advém desses embates, criando a possibilidade de uma terceira narrativa, que questiona a própria instauração do teatro e suas consequências, e, parece-me, que é de total interesse para o teatro feito atualmente.

Para Fischer-Lichte, na análise de caso de algumas encenações (Giulio Cezare, da Societas Raffaello Sanzio, O general do diabo, de Frank Castorf, Rudi, de Klaus-Michael Grüber, e as Áudio-turnês, do Hygiene Heute), há um efeito muito potente numa operação de desestabilização dessa tensão, criando a possibilidade de manter, numa posição de significação análoga, o 
corpo semiótico e o corpo fenomenológico na cena. Uma disruptura na fusão entre estes dois corpos, seja em favor do real, seja em favor do ficcional, força o olhar do espectador a fazer, durante toda a encenação, opções de mirada que não o deixam excluir o termo relegado. Ficção e realidade, sem amalgamarem-se, permanecem em potência similar na encenação. A ficção está lá o tempo todo, mas a realidade força sua presença incômoda, ou vice-versa. A síntese é impedida. A suspensão criada pela não resolução da tensão explicitada imprime, na cena, uma pergunta importante: sobre qual real estamos falando? Numa época em que foi cunhado, até mesmo, o termo "pós-verdade" (depois da acintosa tese da "pós-história"), não é pouca coisa suspender, por uns instantes, o fluxo da ilusão para dizer "péra lá".

Tal tensão também pode ser observada no binômio teatralidade-performatividade, donde o performativo se constituiria pela presença, pela ação, pelo corpo fenomenológico que ocupa um espaço contíguo ao espectador, e o teatral pela representação ou por certa narrativa criada a partir do acionamento relacional constituído pela copresença ator/espectador - ou seja, um discurso, que, portanto, prevê, em sua constituição, um receptor/coautor. Ainda que esses dois campos, teatral e performativo, não possam ser definidos restritivamente e, na maioria dos casos, eles se hibridizem, é na confrontação destes que podemos, de certa maneira, observar a importância de dois aspectos da recepção/espectação da cena: o que ou quem tem lugar de representação e o que ou quem ocupa um lugar de fala. Entendido que essa síntese se dará na cena contemporânea pelas elaborações do espectador no seu processo de recepção, que corpo preenche a cena e que discurso é proposto por ela? Mas essa operação não está restrita ao espaço do teatro, ela, antes, depende de um trânsito muito efetivo entre a cena e a rua, entre as políticas da forma e as formas da política, entre o social e as sociabilidades estabelecidas no encontro entre obra e espectador.

Trata-se, para o que concerne a essa reflexão, de entender o teatro como campo expandido, como diz lleana Dieguez (2014), no qual também afirma que a teatralidade é "um discurso e uma estratégia que atravessa o teatro e o transcende." Sua observação adota os termos da produção crítica das artes visuais de Rosalind E. Krauss e do escultor Donald Judd, para quem a escultura deveria ser entendida, na produção da década de 1960, 
como um campo expandido. Essa perspectiva aparece em resposta à famosa crítica de Michael Fried, de 1967, sobre os malefícios à produção plástica da década de 1960 (especialmente em razão do movimento da minimal art) de uma contaminação das artes visuais que Fried caracteriza como teatralidade. A teatralidade da qual fala o crítico americano está relacionada à presença de objectualidades nas obras minimalistas, que impunham uma experiência ao fruidor, já que constituíam um estar em situação. Do que depreendemos que, ao criar uma experiência, de certa forma, esses objetos propunham um discurso, um percorrer, uma espécie de narrativa/texto. Daí Fried chamar os artistas minimalistas de "literalistas". Para Fried, cabia às artes visuais romper com a teatralidade como ideia de contrabando que ameaçava sua pureza.

O que me aproxima do texto de lleana é a reposição que ela desenha aos termos: a expansão das artes visuais para um campo discursivo não interessa especialmente a autora, o que interessa é entender o teatro como discurso, ou estratégia, que se expande para além da cena. Isso significa perceber que a produção discursiva, dada por um estar em situação e pela demanda a uma experiência (para usar os termos da crítica de Fried), permeia as relações políticas e sociais em espaços diversos que ultrapassam a cena em si, relações que são prenhes de teatralidade.

Para mim, toca, especialmente, a possibilidade de avaliar como essa teatralidade "dá a volta do parafuso" e aparece novamente na cena fazendo as vezes do real. O que equivale dizer: as relações político-sociais, enquadradas por uma teatralidade que Ihes perpassa, retornam a cena como objetivação do real. O jogo de presenças ou não presenças, demandado pelas representações sociais e narrativas, quando retorna à cena, já possui na sua conformação certo grau de teatralidade prévia. Interessa a mim o confronto entre a teatralidade expandida com a cena.

As transformações e expansões do performativo, do teatral, e do cênico não tem ocorrido somente por conta das contaminações e disseminações indisciplinares das artes, senão insistentemente pelas demandas e contaminações que os acontecimentos da vida propõe a arte, pela urgência e com que nos interpelam as cenas e teatralidades da polis. (DIEGUEZ, 2014, p. 129) 
Contudo, se consideramos ainda em operação a proposição de Guy Debord (1997, p. 13) - sobrepondo mais uma camada a esta discussão - de que "tudo o que era vivido diretamente tornou-se uma representação" a partir da modernidade -, teremos de perceber que é sob o signo do risco que qualquer teatralidade presente fora da cena retorna a esta. A teatralidade expandida, observada nas diversas relações de sociabilidades - com sua produção de discurso e suas fendas críticas - e a transposição do teatro cotidiano para cena não estão imunes à espetacularização. Seria preciso, então, criar uma distinção clara entre teatro e espetáculo. E, nesse sentido, serão a posição do espectador e as demandas a ele dirigidas os vetores de maior importância da equação. Helga Finter problematiza essa questão na análise da produção teatral na Alemanha entre as décadas de 1990 e 2000.

Finter (2003), então diretora do Institu für Theaterwissenschaft da Universidade de Giessen, faz uma análise bastante pertinente sobre a confrontação entre a teatralidade e a espetacularização na cena contemporânea. A autora afirma que no "século passado, inovadores do teatro contemporâneo estabeleceram, em três ocasiões, uma cena de rua como modelo de um teatro futuro". A autora elenca Antonin Artaud - quando escreve sobre uma batida policial num prostíbulo em 1926 e descreve a ação da polícia como uma coreografia -, Gertrude Stein - que em 1935, em Lectures in America, defende a participação em uma cena real em contraponto a atividade do espectador de teatro - e por fim Bertolt Brecht - e sua "cena de rua", em $A$ compra do latão, escrita no período entre 1937 e 1951. A leitura da teórica alemã é bastante interessante. Para ela:

Essas três cenas de rua, propostas como modelo de um teatro futuro, contém o germe de estrutura dos três tipos de teatro que determinam a cena teatral a partir dos anos 1960: o teatro da crueldade de Artaud, landscape play e a performance art, e o teatro épico. (FINTER, 2003, p. 1)

O que me interessa nesta leitura é o apelo de Finter ao papel proeminente do espectador diante dessas cenas.

[...] cuja atitude requerida define, em cada modelo, um novo tipo de teatralidade. É sua realidade de sujeito que é interpelada: sujeito do inconsciente para Artaud, sujeito da inconsciência para Gertrude Stein 
e sujeito transcendental de reflexão para Brecht. Por que agora o espectador é jogado para o centro? Porque justamente no período entre guerras, do século passado, recorda-se que do lugar do espectador (theatron) deriva o teatro e de que de sua atividade (theomai - olhar simultaneamente com os olhos e a mente) nasceram os termos teatro e teoria? Ainda que nos três tipos de teatro o modo de atuação seja decisivo - encarnação artaudiana, non-acting steiniano ou gestus brechtiano -, a arte do ator só é determinante por aquilo que em sua atuação contribui para uma reflexão sobre a relação entre teatralidade e espetacular. (FINTER, 2003, p. 1)

Para esta reflexão, cabe entender as relações entre teatralidade e espetacular, conforme propõe Finter. A autora, partindo da teoria de Debord, caracteriza França e Alemanha como lugares, na época da escrita das cenas de rua, donde podíamos falar de uma espetacularidade concentrada, característica de sociedades totalitárias e ditatórias, enquanto nos Estados Unidos já poderia se falar de uma espetacularidade difusa das sociedades pós-industriais:

Na Europa, diante do espetáculo da estetização da política dos fascismos e do direito exigido das massas à autorrepresentação, a resposta tinha de ser distinta: de um lado uma tentativa de fazer surgir, mediante encarnação, a crueldade subjacente à vida cotidiana na sociedade para analisá-la em cena; de outro, a proposta de submissão à encarnação da política ao bisturi do gestus e de desmontar o espetacular pela análise do olhar. A dramaturga norte-americana, por sua vez, originária de um país no qual o estabelecimento do espetacular difuso estava muito mais avançado que na Europa, já reagia em sintonia com uma teatralização da vida cotidiana: efetivamente, isto podia tornar o espectador de uma representação teatral incômodo ou nervoso, por que o colocava em uma distância entre a encenação cotidiana de si mesmo e o desconcerto nascido de uma ausência de memória cultural. Stein concebe o teatro futuro como um puro fazer, construção de presença e superfície, performance nascida de um non-acting. (FINTER, 2003, p. 1-2)

A autora segue para a observação de casos presentes no teatro alemão contemporâneo (elencando especialmente os jovens artistas saídos de Gissen). Finter fala sobre uma espetacularização globalizada como prevalente na atualidade e descreve trabalhos de artistas como Rimini Protokoll, She 
She Pop, Gob Squad, René Pollesh e Christoph Schlingensief. Para a autora, no "centro das produções desses jovens performers e dramaturgos existe, efetivamente, uma relação com a sociedade que, ao mesmo tempo, submete às leis do espetáculo a vida íntima e a vida pública, a memória, os desejos, os medos" (FINTER, 2003, p. 3). Diversos procedimentos e dispositivos são experimentados e acionados na pesquisa dessas relações: desde a utilização de não profissionais, alçados a posição de grandes expositores de seu cotidiano como algo a ser espectado (Rimini), ou mesmo, se autoalçando à posição de pop stars (She She Pop), até a utilização de instrumental pseudocientífico - para repor ideias antidemocráticas disseminadas e reproduzir discursos políticos em jogos de incorporação pela plateia -, evocando uma teatralidade contaminada pelo espetáculo dos mecanismos participativos.

Um caso específico chama a minha atenção pela pertinência ao presente artigo. Finter questiona a radicalidade de Christoph Schlingensief ao forçar certos limites da equação teatro/espetáculo:

Chistoph Schlingensief, cineasta, talk show máster e homem de teatro, intervém na realidade política alemã, suíça e austríaca, desde meados dos anos 1990. Suas ações poderiam caracterizá-lo como um homem do teatro invisível de Augusto Boal ou de alguns situacionistas franceses. Entretanto, seus modelos são explicitamente formatos nascidos da vida midiática e política, já que para ele se trata de fazer confessar - pelos meios do espetáculo - à sociedade do espetáculo o que cala e o que rejeita. Ainda que essa luta impossível de um David das artes contra o Golias dos meios tenha encontrado seus limites no domínio dos talk shows [...], a eficiência das ações no domínio artístico e teatral se comprovou tanto no que concerne a reação dos meios como nas repostas do público, que se dividiu entre opositores ferozes e fanáticos incondicionais. (FINTER, 2003, p. 5-6)

As ações de Schlingensief são radicais. Dentre elas, temos: Chance 2000, que retoma as estruturas de campanhas eleitorais para se lançar candidato de um partido próprio e votar em si mesmo; Ausländer raus-liebt Österreich (Os estrangeiros para fora - Amém Áustria) em que faz uma ação no dia do lançamento do Big Brother da TV alemã, com um grupo de imigrantes que pediam asilo na Áustria sendo filmados por câmeras dentro de um contêiner, perto da Ópera de Viena, e o público do festival Festwochen de Viena, tinha de votar em 
quem deveria ser eliminado e extraditado, conforme critérios de simpatia; Quiz 3000 - Du bist die Katastrophe (Quiz 3000 - Você é a catástrofe), um programa de perguntas e respostas em que o candidato era levado ao desastre moral e a total vergonha ao responder perguntas como: "Para que serviam o pelo das vítimas dos campos de concentração?" ou "Ordene de norte a sul os seguintes campos de concentração: Auschwitz, Bergen-Belson, Dachau, Ravensbrück"2.

Finter (2003, p. 5-6) lembra, porém, que o limite da ação de Schlingesief "falha quando se trata de falar do terror que se teatraliza". Em 2003, um parlamentar alemão cometeu suicídio e as reações dos meios à essa notícia recordavam uma ação realizada por Schlingensief no festival Theater Der Welt, quando pisoteava a foto deste deputado, que havia sido acusado de antissemitismo por declarações ambíguas, gritando "Matem, Matem".

A significação desse evento supera o caso isolado de Schlingensief, já que, inclusive por ser o artista que mais contribuiu na Alemanha no domínio das artes para uma supressão virtual dos limites entre vida e arte, entre espetáculo da vida e vida de teatro para exibir sua contaminação mútua, se um Aktionskünstler (performer) recorre - apenas o impacto da violência de suas ações corre o risco de repercussões no real - à reinstalação da separação entre vida e arte, então uma suspeita se insinua. A eficiência simbólica da transgressão de dois espaços dependeria em última instância da existência de um marco reconhecido no âmbito das artes? E a condição de um marco semelhante não é justamente, a separação pressuposta, em uma sociedade, de dois espaços distintos: espaço potencial da arte e do teatro, e o campo da realidade social? (FINTER, 2003, p. 6)

Para Finter, o teatro alemão ampliou nos últimos anos, significativamente ao marco do teatro, a separação entre vida e atuação. Mesmo o público perde seu lugar de origem ao converter-se, a torto e a direito, em atuante, performer, ator. A teatralização da vida cotidiana também se mantém na berlinda. Trata-se de um questionamento entre as fronteiras do espaço estético e do espaço real que leva, a todo instante, a questão da validade de um modelo pré-existente e a identificação do artifício.

2 É sempre bom lembrar que, embora Hitler fosse austríaco e o governo da Áustria ter participado ativamente da perseguição antissemita, trata- se de um país que nunca fez um mea culpa, como o fez a Alemanha, e tem atualmente um dos maiores partidos de extrema direita da Europa, o Partido da Liberdade da Áustria. 


\begin{abstract}
Mas, simultaneamente, ao confrontarmos esse modo com a realidade do espetacular integrado, desvelam o pressuposto dessa sociedade do espetáculo: a existência de um espaço intermediário das artes que justamente oferece seus artifícios de verossimilhação, seus instrumentos de transformação de suas imagens em natureza. A sociedade do espetáculo falha pela representação, mas também é de seu direito à representação em um espaço reservado que pode nascer a sua crítica. Por outro lado, a proibição da representação, a supressão desse espaço só leva ao terror. (FINTER, 2003, p. 8)
\end{abstract}

Ainda que Erika e Finter caminhem por percursos bem diversos, tento aqui, por hora, encontrar um equilíbrio possível dos elementos evocados para refletir um pouco acerca da representação da violência no teatro.

Saliento dessas reflexões dois aspectos: uma prevalência do ato de espectação ${ }^{3}$ como, por um lado, resultado da espetacularização do cotidiano, por outro, como ato potente de produção das narrativas por meio do entendimento da teatralidade expandida. Volto a sublinhar que produção de narrativas (e prevalência, ausência ou desqualificação de narrativas) vem sendo usada como mote de luta por diversas minorias que não se sentem/não são representadas neste cotidiano. Ou seja, a criação de uma narrativa que nos represente e que represente o outro depende do acionamento da potência desse espectador como produtor/receptor de discurso. Daí a importância de desestabilizar, usando as palavras de Fischer-Lichte, o espectador e, na problematização desse real na cena, criar a possibilidade de outras narrativas que fujam do padrão espetacularizado do real.

\title{
Representação da violência
}

Parto para análise de duas experiências do Coletivo Bruto no tratamento da violência no teatro, não desprezando o caráter documental, portanto, e teoricamente, excerto da realidade, da cena.

3 "O espetáculo apresenta-se ao mesmo tempo como a própria sociedade e como instrumento de unificação. Como parte da sociedade ele é expressamente o setor que concentra todo olhar e toda consciência. Pelo fato de esse setor estar separado, ele é o lugar do olhar iludido e da falsa consciência; a unificação que realiza é tão somente a linguagem oficial da separação generalizada" (DEBORD, 1997, p. 14). 
A primeira experiência ocorre na encenação de $O$ que está aqui é o que sobrou, dramaturgia organizada por Paulo Barcellos a partir da criação do Coletivo Bruto acerca de O declínio do egoísta Johann Fatzer de Brecht (2002).

A sinopse da montagem é a que segue:

Um grupo de documentaristas, reclusos em uma "ilha de edição", debatem como finalizar um difícil trabalho de reunir entrevistas gravadas em vídeo e na web. Essa ação é entrecortada com trechos da peça $O$ declínio do ego ísta Johan Fatzer, de Heiner Müller e Bertolt Brecht. Envolvidos por um emaranhado de imagens reais e ficcionais, o grupo fracassa em sua tarefa quando a violência cotidiana se volta contra eles próprio. O que resta é abandonar suas velhas ideologias na tentativa de encontrar uma saída e planificar o aprendizado coletivo. (COLETIVO BRUTO, 2012)

O tema do pretenso documentário que essas personagens tentavam finalizar, embora não expresso diretamente, claro por imagens e referências textuais, era a Batalha de Pinheirinho, ocorrida em 2012, período em que realizávamos a pesquisa.

Ao buscar na rede uma descrição sobre essa "batalha", deparo com uma análise que utiliza, curiosamente, o termo cena para descrever epicamente o que ocorrera na desocupação. Pela confluência com o tema aqui tratado, reproduzo parte da descrição feita pelo Coletivo Usina ${ }^{4}$ e publicada no site Diário Liberdade.

Um lado menos visível do Pinheirinho, onde não foram reprimidos apenas pobres "invasores", mas toda uma organização política e espacial. $\mathrm{O}$ ataque ao Pinheirinho foi um ataque a todos os que lutam por outra sociedade e por outra cidade.

\section{Cena 1}

Quem se aproxima da enorme ocupação já a reconhece por meio de uma alameda de pinheiros altos, cercas feito barricadas, com lanças de bambu apontando para a rua e bandeiras vermelhas dependuradas, pedindo apoio, estimulando a luta. Lá dentro, o espaço da associação de moradores fica logo na entrada e é acessível a todos. [...] Frente a es-

4 Coletivo de arquitetura e política formado há 21 anos que apoia movimentos de luta por moradia, reforma urbana e reforma agrária em projetos autogestionários de construção civil e transformação de territórios. Ver: <http://usinactah.org.br>. 
cusos interesses privados, que insistem na reintegração de posse para fazer valer o direito supremo da propriedade, as ruas largas veem surgir as barricadas, que prometem resistir.

\section{Cena 2}

[...] No céu, helicópteros mantêm a área sob vigia enquanto na avenida da ocupação um forte esquema militar bloqueia todos os seus acessos. Sob o olhar vazio de dezenas de policiais, uma família sai do terreno em direção à cidade. Uma mulher chora e carrega um saco de lixo nas costas, com os pertences que conseguiu juntar. [...] Policiais invadem casas da vizinhança, como se buscassem pessoas específicas. Mais à frente, chegamos a uma praça cercada por grades com grandes tendas brancas onde centenas de pessoas se amontoavam num lamaçal cheirando a estrume. Os ânimos estão exaltados. De repente, uma grande gritaria. Crescente. Forte. A reintegração parecia ter sido cancelada. Muitos começam a correr em direção à saída para tentar voltar para suas casas. Uma comemoração passageira. Confusão, mais tiros. Apesar da gritante desproporção de forças, jovens desesperados extravasam sua revolta arremessando objetos e pedras na direção dos policiais, que respondem com tiros de balas de borracha e bombas de efeito moral. A reintegração continua.

Famílias se enfileiram para conseguir cadastro, assistência social, abrigo, comida. São oferecidas passagens para os que quiserem retornar a sua terra de origem. Chamam o espaço de Triagem. Adquirem senhas. Pulseiras de identificação. Viram números. (COLETIVO USINA, 2012)

Como uma rubrica cênica, recorte de teatralidade expandida, o narrador presentifica um discurso teatral para descrever uma situação real, que desenhara uma coreografia medonha que, infelizmente, se tornaria mais corriqueira nos anos vindouros. A imagem era um espanto. Que teatro daria conta daquilo? Que teatro?

Talvez a melhor representação dessa violência tenha sido adotar secamente essa narrativa, mas a encenação de O que está aqui é o que sobrou jogava, exatamente, com a impossibilidade de transpor essa violência para cena. A formatação da cena real estava fadada ao assédio pela espetacularização.

Durante a encenação, edições de vídeo, tratando pretensamente de Pinheirinho, eram apresentadas por seus personagens autores e debatidas pelos demais. O consenso sobre o encaminhamento formal do trabalho nunca era alcançado. A cena ocorria cercada por três grandes telões que apresentavam, várias vezes, uma profusão de imagens. Logo no início da encenação, 
os atores posicionavam-se ao redor de um pinheiro de natal, simplório, e permaneciam em silêncio, observando. A ação era subsequente à enunciação de um trecho do Fatzer, em que é dito:

IELTXU - Minha mãe é um tanque de onde atiramos. Ninguém pergunta por nós. Estamos perdidos. Chegamos tarde ou cedo demais. Tudo tem que ser aniquilado. Ali ainda tem uma árvore. Ela também tem que ser derrubada. Alegrem-se, lugar errado. (COLETIVO BRUTO, 2012)

Após observarem o pinheiro, é iniciada uma conversa um tanto cifrada, que segue:

JULIÃO (olha o pinheirinho) - Seco.

(pausa)

LUIZ - Silêncio, né?!

IELTXU - Tudo parado.

PAULO - Então, a parte dos caras correndo, onde tem... Os caras gritando, sabe? Eu, não sei, eu gosto daquela parte... Sabe qual é?

IELTXU - Sei.

LUIZ - Tem que tomar cuidado pra não segmentar muito.

JULIÃO - É, eu não sei. Porque esse trecho aí, que nem aquele outro lá, daquele velho, o senhor...

IELTXU - Tem que ser mais pã. Precisa ter, tipo, pá.

JULIÃO - Não tem, não tem, não tem! Não tem um negócio aí. Não tem. Falta!...

IELTXU - Precisa mais, mais, mais! Ah, deixa pra lá. Depois eu falo.

LUIZ - Tá meio escancarado!...

PAULO - Eu acho que a gente precisa começar, e depois ver o que acontece.

LUIZ - Mas precisa tomar cuidado com isso. Pode ser precipitado demais.

PAULO - Claro, claro, começar, ver o que acontece mas no meio tem um, tem tipo uma terra arrasada, assim, tem um fracasso total, não tem nada no meio... né?!

IELTXU - Eu gosto muito quando tem aquele monte de cara - "ratarataratarata" - você não sabe muito o que vai acontecer - "pá!" - Que porra é essa?

PAULO - ... E para.

JULIÃO - Slow...

PAULO - Que porra é essa, "para"?!...

JULIÃO - ... slow...

PAULO - Para. (pequena suspensão) 
IELTXU - Também podia ser, sei lá, mais, ser meio picotado, tatatatatatatata.

PAULO - É, pode ser, mas...

JULIÃO - Linguagem.

LUIZ - Eu não sei. Tô achando que não tá, sabe?!

IELTXU - Espera... espera... espera o momento certo... espera... e OLÉ.

PAULO - ... mas e o fim?

JULIÃO - Que fim?

IELTXU - Que porra de fim?

PAULO - Acho que tem que começar e Tum, Tum, Tum, Tum. Depois mistura... mas... depois tem o fim, sabe, não tem nada, nada. Tem uma terra arrasada, assim, tudo deu errado...

LUIZ - É, eu tô de acordo.

JULIÃO - Não, espera, espera. Acho que chegamos num lugar. (COLETIVO BRUTO, 2012)

A cena subsequente à discussão sobre o formato da edição era uma subversão da possibilidade de uma representação em si. Se a discussão demonstrava a total incapacidade das personagens darem conta do material tratado por meio do recorte poético, pois mesmo que estivessem de acordo, nenhuma das ideias reflete a potência do acontecimento, a cena seguinte instaura um desacordo acerca da concretude do real.

Os atores estão cercados por uma "enxurrada" de imagens projetadas de material bruto nas três telas. Essas imagens são as mais diversas. Julião diz: "Tem um ponto aí, muito, muito. Solta"

Entra vídeo de um ataque noturno filmado com câmeras de captação no escuro, televisionado por uma rede internacional de notícias, na cidade de Bagdá, durante a Guerra do Iraque. Cena quase bela. Já na sua primeira recepção, em 1991, quando todos a viram em uma inaudita transmissão ao vivo da ocasião, inaugurava uma estetização inédita da guerra, creio que só superada pelo corte cirúrgico do World Trade Center por dois aviões em 2001 - "A maior obra de arte já realizada", como disse Karlheinz Stockhausen em uma fala que, tirada do contexto, o prejudicou para o resto da vida.

O ator faz uma descrição da imagem que não corresponde ao que está sendo mostrado. Ele ilumina pontos luminosos (bombas) com uma caneta laser, como se fossem elementos da narrativa. O texto que ele diz é uma ex- 
planação, presente no texto de Brecht, sobre o destino dos quatro soldados desertores da fábula do Fatzer, misturada às considerações concernentes à proposição poética de sua personagem.

JULIÃO (apresenta a guerra ao vivo show) - Já que esses homens, essas pessoas todas aí deixaram tudo o que tinham pra chegar num outro lugar que ainda não sabem, não conhecem o que vêm pela frente... Às vezes dormindo assim, no relento, que nem cachorro, que nenhum de nós aqui já passou por isso. Mas que ficam completamente isoladas, na espera de um mundo melhor, pensei que esse lugar poderia ser apresentado internamente, como uma vertigem, sabe? Causar uma estranheza em quem vê para sentir um pouco do que eles sentem, sabe?! Acho que temos um lugar aí, um ponto de partida. (COLETIVO BRUTO, 2012)

Outro ator (Paulo) reclama da inutilidade da proposta do primeiro (Julião), ao que este responde que falta clareza no posicionamento do segundo:

PAULO - [...] Está faltando a parte do deserto! Estamos perdidos! É o fim! Deu errado! Errado! Isso não serve pra nada. [...] A minha proposta não é clara! Por que você acha que uma proposta deveria ser clara! Eu não quero ser claro! Eu quero que se foda a clareza! A minha proposta é obscura e sem sentido, e sem porra nenhuma! Isso que você fez é realmente claro, de uma clareza aviltante para mim! (aponta o sofá) Você sabe o que é isso? Sabe? Um sofá. E serve para alguém descansar. E isso? (um copo de água) Para reter o líquido enquanto matamos a sede. E isso? (aponta a tela). E isso? (aponta a frase no chão). (COLETIVO BRUTO, 2012)

Paulo, que rebate Julião enquanto mostra os objetos, pula sobre o sofá. Se agarra à materialidade do real que já não consegue ser captado pela representação. Fala agressivamente. Julião se enfurece. A violência, que não consegue ser traduzida nas imagens, torna-se entrópica.

Até o final da encenação, alguém deverá ser condenado à morte, como o Fatzer da fábula. Até o final da temporada, os membros do Coletivo brigam e as relações se desgastam. Teatro e vida, assim misturados, sem conseguir escapar às armadilhas do próprio entrave da representação sobreposto ao entrave de um projeto social que demanda um rompimento. Teatro ineficaz. Teatro que não serve. Vida sendo consumida pela Guerra Total, que faz suas vítimas mais escancaradas nos despejados de Pinheirinho. 
Mais à frente, em uma cena com uma espécie de questionário que deve ser respondido pelos atores, em que os "interrogados" se revezam frente a um paredão, donde eram alvejados por bolinhas plásticas, lançadas pelos demais:

PAULO p/ JULIÃO - Qual é o grau de violência que devemos captar? JULIÃO - São graus diferentes... (demora para continuar e leva bolinhas) PAULO - Responde.

JULIÃO - Eu já apanhei. Não preciso mais responder.

LUIZ - Não, tem que responder. Até responder adequadamente. JULIÃO - Tem que colocar violência. Explícita. Pensar que a tela é grande. Pensar que as pessoas vão ficar lá. Atordoadas. É uma violência da edição das imagens. A construção da imagem. O lado da experiência humana terrificada. A construção do cataclismo visual. É disso que a gente precisa. JULIÃO p/ IELTXU - Onde nós vamos conseguir essas imagens? IELTXU - YouTube.

JULIÃO - Então, não vamos gravar porra nenhuma?!

IELTXU - YouTube, YouTube.

PAULO - Então, você não vai pra rua? Vai ficar na frente do computador em sua casa?

IELTXU - Youtube. Youtube.

PAULO - Você acha que no Youtube tem violência suficiente?

IELTXU - Ô, se tem. (descreve) O público tem que entender que a violência está dada, absolutamente cruel.

JULIÃO p/ LUIZ - Como você relativiza essa proposta dele dentro do fato que necessitamos de mais drama social?

LUIZ - A gente tem que analisar que a proposta dele é uma ilusão, mas tem um fundo de verdade.

IETXU - Explique-se.

LUIZ - A proposta dele é de neutralização da realidade aparente.

PAULO - Porque você relativiza nossas questões de um jeito tão falacioso? LUIZ - Eu não falo falácia. Eu falo uma verdade. E você? Não acredita em verdade nenhuma?

PAULO - Eu só acredito na verdade concreta? Joga, joga, ao menos uma vez façam algo de fato!!

PAULO p/ JULIÃO - Como você acha que devem ser captadas as imagens? JULIÃO - Câmera na mão. Glauber Rocha renascido dos infernos. Saturar a imagem. Isso vai mexer com o sistema nervoso das pessoas.

IELTXU - Isso é meio pop.

PAULO - Você quer mostrar o conflito social ou o seu próprio conflito? JULIÃO - Não mostra realidade nenhuma. O que a gente faz é ficção.

PAULO - Então por que precisa ir até a realidade pra fazer ficção? Contrata uns atores de merda. (Representa) _Eu tava em minha casa e vieram uns soldados e acabaram com tuuuudo. Invadiram o Pinheirinho!!! Depois volta pra sua casinha para dormir na sua caminha. Ah, tomá no cu. 
IETXU p/ LUIZ - Por que você acha que tem mostrar conflito de classe? LUIZ - Tem que mostrar conflito de classe porque eles são os motores da história.

PAULO - Isso é você quem acha ou você leu em algum lugar?

LUIZ - Eu li e concordo. Li muito.

JULIÃO p/ LUIZ - Quais as classes envolvidas?

LUIZ - O proletariado e a burguesia.

JULIÃO - Só?

LUIZ - Só. As outras classes são espectadores da história.

IELTXU - Você acha que existe ainda proletariado?

LUIZ - Claro que existe. O, o, o, o...

JULIÃO - Gaguejou.

IELTXU - É uma gaguejada burguesa.

PAULO - Esse espectador fica do lado de quem?

LUIZ - Depende. Alguns do lado da burguesia, outros beneficiários do proletariado.

PAULO p/ IELTXU - Você acha legítima a violência?

IELTXU - Quando não se tem o que comer, sim. (COLETIVO BRUTO, 2012)

No fundo, o que era colocado em questão era uma adesão de uma classe média à luta proletária (ou das minorias expropriadas) em paralelo à incapacidade da arte de sair do seu pequeno círculo de atuação. Dominados pelo código do espetáculo, e, permanecendo fechados em nosso teatro falido, não alcançávamos a teatralidade expandida da violência real. Expúnhamos, em cena, nosso próprio ridículo. O operador de som e luz da encenação (apelidado, na vida, de Rato), em dado momento, tomava o microfone e humilhava os atores:

RATO - Vocês se acham muito justos, vocês se impõem teorias sobre o bom ou o mal gosto. Mas a boca de vozes tem um gosto morto. Vocês lutam uma luta pelo lado de fora. A mim não interessa saber o que é justo. Vocês estão juntos por interesse, e o interesse é sobretudo uma causa nobre, mas não conseguem se suportar. Porque para corpos suados, sobrepostos, com um hálito podre de fome, um carinho não é sinal de cuidado. Ninguém suporta se ver refletido na incompetência do outro. Por que o hálito de vocês é um só, e não é melhor do que de ninguém!!!! E AÍ, VOCÊS QUEREM CARNE OU LUTA? JULIÃO - Carne.

LUIZ - Carne primeiro.

IELTXU - CAR-NE!

(Paulo quieto. Pausa.)" (COLETIVO BRUTO, 2012) 
A contradição do enunciado é que a carne só seria conseguida com a luta.

Uma das questões surgidas da experiência com a encenação de $O$ que está aqui é o que sobrou, por um lado, é que de fato a arte fazer crítica de si mesma não significa seu engajamento real - e se isso se aplicava à ficção encenada, também poderia ser ampliada à própria ineficiência da encenação, fadada a só repor uma questão interna das dinâmicas dos grupos teatrais -; por outro, a discussão das formas pode, sim, levar ao debate, minimamente, questões sobre a representação. Representação, senão da violência, como reposição da violência real, mas da violência intrínseca ao ato representacional em si, à criação de narrativas, repondo-a como presentificação de uma construção ética do processo. Real e ficcional, neste caso, conjugados, dariam notícia não apenas de um debate sobre as relações entre vida e arte, mas também sobre as dinâmicas micropolíticas das relações éticas estabelecidas no interior do coletivo, que refletiriam a macropolítica das ruas. E assim passo para a segunda experiência do Coletivo Bruto.

\section{Presentificação da ética}

Em 2013, eu, junto com Paulo Barcellos (deste momento em diante, o núcleo duro do Coletivo Bruto), me mudo de São Paulo para assumir um cargo da orientadora de Artes Dramáticas do Teatro da USP (o que equivaleria, no caso das funções exercidas, a uma mistura de educadora e gestora cultural para a linguagem do teatro) em um campus do interior do estado de São Paulo.

$\mathrm{Na}$ cidade em que moro, depois de um choque de realidade, ao sair de um centro absolutamente cosmopolita, me deparo com uma realidade muito mais delineada em sua herança oligárquica e de uma grande fragilidade no que diz respeito ao acesso à arte contemporânea (podia falar até mesmo sobre arte moderna, mas não entrarei no mérito). Minha dificuldade de diálogo com a produção teatral local é patente. Trabalho, há dois anos, com um núcleo de poucos alunos tentando tornar concreta alguma produção. O esforço é vão. Foi preciso rever minhas estratégias. Neste contexto, concluo que, embora não fosse um campo de meu interesse específico, um trabalho com princípios de teatro documental, feito em módulos, poderia ser uma ponte de comunicação com os artistas locais. Considero também que, partir de experiências reais dos 
participantes e da história da cidade, contribuiria para a revisão de um lugar assumido pelos artistas locais. Lugar um tanto caricato, por um lado - quando se esmera por encenar peças sobre a figura fictícia do "caipira" - e, por outro, estereotipado de um teatro que almeja chegar a uma profissionalização, importando modelos desvinculados de seus processos geradores - característica de um teatro amador que tenta repor o teatro profissional sem o seu lastro.

Inicio o primeiro módulo em 2015 e, ao final do ano, depois de um segundo módulo, concluo com a apresentação de uma intervenção chamada Ato de espanto sobre nossas mães, amigas e artistas, enquanto preparamos um ceviche. O título é meio autoexplicativo: tratava-se da apresentação de relatos sobre mulheres ao mesmo tempo em que ceviche era preparado por performers $^{5}$, e servido aos espectadores após a intervenção. Esse trabalho veiculou diversas histórias pessoais bastante fortes e deu, a mim e a Paulo Barcellos, a dimensão do que poderia ser o segundo trabalho de uma trilogia que vínhamos desenvolvendo como Coletivo Bruto.

Em 2014, como Coletivo Bruto, em associação a um coletivo local chamado Coletivo Estalo, ganhamos o edital do PROAC para montagens inéditas, com o fim de iniciar uma pesquisa, grosso modo, sobre a formação de uma identidade do interior paulista como paralelo à formação de uma identidade nacional. Para esse primeiro edital, montamos o trabalho Mentira. Em 2015, resolvemos levar adiante nossa pesquisa, agora utilizando parte do material surgido nos módulos de teatro documental e convidando dois atores que dele participaram (mais uma atriz que se integraria ao processo). Assim surgiu o projeto Documentário Vergonha, que deu origem à encenação de Vergonha.

A montagem Vergonha inicia com uma fala minha (que estou em cena também, sob a direção de Paulo Barcellos), alertando o público para o fato de eu sempre ter estado no "lugar errado". Obviamente é um preâmbulo confessional, sobre minha própria posição na cidade como estrangeira. A partir desse relato, relembro uma história real, como todas as outras integrantes da peça, sobre uma crise de pânico que tive na infância, ao não me ver repre-

5 Escolheu-se usar o termo performer por considerar esse trabalho mais performativo que teatral, pois era engendrado por uma série de programas performáticos que enquadravam as narrativas. 
sentada - por outra, me ver oprimida por uma representação - em um documentário sobre o desenvolvimento da indústria brasileira no período ditatorial.

MARIA - Eu sempre estive no lugar errado. Não. Eu estava lá, mas lá era o lugar errado. Tsc. Eu sempre tava errada no lugar. Não. Eu estava fora do lugar. Eu estava de fora, do lugar. Não, eu estou aqui e tá tudo errado. Que bela bosta! Eu estou me esforçando. Eu vou começar de novo. Cine Havaí, 1978. Meu pai me leva ao cinema para ver um filme da Disney, acho que era a Bela Adormecida ou Branca de Neve, não lembro. Chegamos ao cinema e antes de começar o filme, na tela enorme, filme bitola $70 \mathrm{~mm}$, um filme moderno, os documentários usuais do canal cem. Com aquela voz masculina e grave, um futebolístico e outro sobre notícias. Era o segundo caso, uma reportagem sobre os avanços da indústria alimentícia brasileira. Na tela, uma imagem gigante de carne, de bois pendurados numa esteira mecânica com ganchos. Tudo muito limpo. As pessoas de branco, muito higiênico. O futuro tinha chegado. Eu parei entre a luz da rua e a escuridão da sala iluminada pelo progresso em série na tela, com a imagem de desfile de carnes de boi pendurados e uma música muito alta. (Para) Tive um ataque de pânico. Comecei a chorar aos berros. Meu pai teve que me levar para casa e eu não vi o filme. Acho que foi lá que eu entendi que eu não tinha lugar naquela imagem. Não era boi, mas também não era boca que come o boi. Ou era boi e boca, mas era olho também. Eu via aquilo tudo acontecer, de fora. Bom, desde então, pra esconder este terrível segredo, eu aprendi a me camuflar para tentar sobreviver ao terror. Estar lá e não estar também. Perceber e passar despercebida. Camuflagem. Essa peça também tem uma história que aos poucos será escondida e passará despercebida. (COLETIVO BRUTO, 2016)

Essa fala emoldura o primeiro ato da peça que é composto por três linhas narrativas: relatos sobre a infância dos atores, imagens e discursos dos presidentes do período ditatorial em projeções e uma sequência de etapas de um abate de boi desde sua chegada ao matadouro até a forma final dos cortes de carne, também em projeções. Durante todo o primeiro ato, fica claro que eu comando a peça. Eu mando nos outros atores, faço comentários, dialogo com os vídeos. Eu não me comovo com as narrativas. Eu mando os demais terem coragem de se expor. Os relatos são íntimos e, na maioria das vezes, muito violentos. Vão desde a história da mãe que foi vendida para uma família de fazendeiros para trabalhar de graça e acabou se casando com um dos filhos da família que a estuprou (um dos atores é filho dessa união), até a falta de comida ou a violência domestica; o abandono pelo pai que viu a própria mãe ser atingida 
por uma bomba na Itália, na segunda Guerra Mundial; o analfabetismo da mãe nordestina etc. As histórias são todas muito violentas, mas são contadas com bastante delicadeza. Em contraponto, minha personagem relata também histórias de infância, mas sempre com um recorte claramente histórico e engajado. Ao final do primeiro ato, sem a minha presença, os outros três atores convidam a plateia a dançar ao som de My way, de Frank Sinatra, num jogo pueril de "dança da vassoura." O primeiro ato termina com a plateia envolvida pelo sensível e com uma identificação clara com as vicissitudes da pobreza e da vergonha.

O segundo ato muda completamente o registro até então dado. Uma mesa de ferro invade a cena, e uma copeira a prepara para ceia - deduzimos ser de natal por um vídeo do presidente Sarney, em rede nacional, mandando uma mensagem de fim de ano. A copeira é a única personagem ficcional da montagem. Ela é interpretada por uma bailarina-atriz que, até então não, havia aparecido em cena. Minha personagem se senta sozinha à mesa e espera a entrada de outros personagens. O tom, dos demais, já de início é histriônico. Eles riem. Eles riem quase ininterruptamente por todo o segundo ato. Uma sopa e vinho são servidos para os atores-personagens pela copeira. Os três começam a recontar as mesmas histórias que haviam contado no primeiro ato, com uma ou outra variação. Mas, dessa vez, contam na terceira pessoa e riem largamente daquela gente pobre. Um deles alia um tom machista aos relatos, só salvando a própria mãe da sua chacota. A outra, além de reiterar o discurso machista, ri da exploração e do abando de si mesma pelo pai. O terceiro, mesmo tendo confessado a pobreza e a homossexualidade no primeiro ato, recheia seus relatos de comentários homofóbicos e classistas. Eu permaneço elencando histórias de infância, na primeira pessoa, totalmente deslocadas de contexto. Fica patente a minha arrogância, o meu deslumbre intelectual e um tom de superioridade disfarçado por um olhar, inicialmente condescendente e "inclusivo". Os demais se rebelam contra minha arrogância, me interrompem, jogam água na minha cara, me ridicularizam. A copeira entra e sai da cena para servir e, a todo o momento que entra, os três atores se calam - como se certos assuntos não devessem ser conversados na frente dos empregados. Além da agressividade para comigo na cena, a minha personagem vai se chocando cada vez mais com os comentários racistas, preconceituosos e violentos dos demais. A plateia também segue se incomodando. A copeira entra mais uma 
vez para servir algo. Ela é expulsa da cena pela atriz que, apesar de ter contato que servia mesa durante toda a infância na pensão de sua avó, reclama da cara da empregada e vaticina: quem nasceu pra servir mesa, vai morrer servindo mesa. Já no auge do desespero, começo contar uma história sobre Cuba, num total deslocamento e num absoluto lugar comum da imagem de comunista. A copeira volta à cena, pega um microfone e xinga os outros três atores com uma longa lista direcionada a cada um. Em dado momento, eu começo a aplaudir. Ela se vira para mim e diz: "E você, não se meta!". Sai de cena. Os atores pausam por alguns instantes e voltam a gargalhar como antes. Cada um faz um relato final ainda na terceira pessoa, sobre uma não perspectiva de futuro: um quer o sucesso que nunca terá, o outro não reconhece nenhum fato em sua cidade, a não ser fatos do passado, pelos quais possa se orgulhar, a atriz fala sobre uma vingança absolutamente tola ao desprezo de seu pai, envolvendo a compra de um pacote de fidelidade em um salão de beleza. Terminado os textos, começa um vídeo com uma mensagem de fim de ano, da época da ditadura, pregando a igualdade entre todos os brasileiros. Eu pego o microfone e, de costas, após me despir, digo o seguinte texto:

MARIA - [...] Penso sobre o orgulho e a legitimação do meu lugar no mundo, um pouco acima dos demais, mas, nem tanto. Quem está por baixo, pelo menos está livre de cair, diz o ditado. Mas também diz: Modéstia em excesso não deixa de ser meia vaidade. Reflito se a ausência de punição a um crime é na verdade um perdão. Um crime sem motivo, um crime não punido. Se eu não vou ser punida por minha arrogância de estar acima dos outros - elevada, classe alta, branca, olhos azuis, ascendência europeia, intelectual - por que, me diz, por que eu me esforço por parecer humilde, por me irmanar com os desgraçados? Por quê? Que arrogância conceitual me impele a achar que a injustiça social deve ser corrigida. Pois veja, e isto é Milton Santos, "O Brasil jamais teve cidadãos, nós, a classe média, não queremos direitos, nós queremos privilégios, e os pobres não tem direitos, não há, pois, cidadania neste país, nunca houve!" Por que diabos, eu, um dia, vi um cara na TV, que estava preso porque tinha feito greve e tava todo lascado e pensei, é com este cara que nós devemos ficar? Por que quando havia alguém torto, tonto, deslocado na escola, era comigo que ele se identificava? E era só eu que não tinha cara de dizer: Saí daqui! Eu não quero ser torta, tonta ou deslocada! Eu da classe média-elite-europa-cultura-refinamento deitada em berço esplêndido quero ainda por cima ser SANTA, ou ainda não suportaria a falta de classe de rejeitar alguém. Mas é um desejo bem verdadeiro, bem 
verdadeiro mesmo. Eu passo mal, eu fico enjoada, eu quase morro em explosões de raiva de ver injustiças. As injustiças são uma falta de refinamento decerto. As injustiças são vergonhosas. As injustiças, não são justas, ajustadas. São frouxas, lassas. A injustiça social transforma os corpos, em corpos sem tônus. As injustiças sociais amassam os corpos moles como bife de coxão mole, no martelo. Carne morta, fria. Carne para ser degustada com garfo e faca, e guardanapo e decência e boca fechada e nada de cotovelos na mesa e mãos na parede e comporte-se, renda-se, vire-se, sente-se, agradeça-se a si e a Deus por ser: ELITE. Tudo bem, eu poderia dizer que sim, eu me sentia excluída, fodida e torta. Na verdade, papai mamãe hippies, a gente não tinha telefone, não tinha pratos e copos duralex, não tinha TV a cores, não tinha carro bom, papai nem dirigia, papai tinha barba, papai bebia, a gente tinha medo da polícia, vovó fugiu dos nazistas, mamãe não vai ter dinheiro este mês. $\mathrm{E}$ eu, eu estranhona, panicada, meio eu não gosto de ninguém, e todos tão bobos e chatos e coniventes com as injustiças. Gente burra, que fala do passado como se fosse bom, gente que nunca plantou uma alface, que não tem esse conhecimento. Que só repete o que o dono fala. E o dono também não pensa, mas tem dinheiro e paga pros outros pensarem por ele. E imagina o pânico ir jantar na casa dos colegas de escola, gente de bem, com duralex, com sobremesa, com mãe em casa cozinhando, com decência e fervor civil. EU TINHA MEDO!!!!!!!!!! (COLETIVO BRUTO, 2016)

Então, eu me viro e, numa atitude autoritária, expulso os três outros atores para finalizar a peça e receber os aplausos sozinha: estou nua. A plateia fica num silêncio constrangido. Minutos de uma sensação de total desestabilidade. Às vezes, um espectador pergunta para o outro: É pra aplaudir? O que faço agora?

(Ela grita com os outros atores de cima da mesa) Agora chega! Chega de vocês! Sai! Sai agora. Eu tô mandando. (Para o público) Agora vocês... Vocês. Vocês podem aplaudir. Acabou. É o fim. Façam alguma coisa. Aplaudam. Querem uma musiquinha pro final? (GRITA) Põe a porra da musiquinha pra aplaudir. (COLETIVO BRUTO, 2016)

Saio correndo mandando o público "à merda". Surge um vídeo, "bem cinema nacional anos 1960", com minha imagem nua correndo num pasto no meio de bois ao som de "Meu relógio parou, e parou para sempre de ser...," dos Mutantes. 
A peça é absolutamente desagradável. O público reconhecia-se muito facilmente nas imagens, mas não conseguia permanecer em um ponto isento. Ninguém se salvava.

O que saliento, porém, é uma predisposição à presentificação de um acordo tênue de convivência e a exposição da ferida da precariedade que origina um enorme reacionarismo na forma de "valores." Valores que não mudaram desde 1964. A forma, também, ainda é a mesma. As frases de Médici são repetidas por Sarney, por Collor, por Temer ${ }^{6}$. A propaganda de final de ano desperta na plateia o canto: todos conhecem a letra, todos a consideram sua. $\mathrm{Na}$ cena, com toda a dificuldade que é se expor nesse nível, os atores se deixavam ser conduzidos e julgados pela minha pessoa, em suas deficiências, assim como deixavam claro que, sim, às vezes dá vontade de jogar água na minha arrogância de estrangeira. O processo de montagem, sempre pactuado entre todos, não igualou as perspectivas de cada um. As diferenças estão em cena. A violência não se dissipa. Este estado de uma ética presentificada, no qual os atores se dispõem a posicionarem-se em suas faltas, mas não abrem mão de sua posição numa sociabilidade que já está dada fora da cena, subverte o pacto pacificador que envolveria a plateia e colocaria o espectador em um lugar seguro. O Brasil está na cena. E o Brasil somos todos nós.

Concluo com algumas considerações que deverão ser conjugadas, sempre em grau de igualdade, para que possamos vislumbrar a potência desse espaço que é a cena. Em primeiro lugar, é preciso observar que a teatralidade se expande para fora da cena como discurso. As narrativas, engendradas pela teatralidade expandida, podem, por sua vez, serem libertárias ou aprisionantes. Em segundo lugar, é necessário ter em foco que a sociedade do espetáculo integrada tende a absorver quaisquer narrativas para sua órbita de influência, tornando o real em ficção e vice-versa. O aprisionamento de narrativas pelo espetáculo é um risco verdadeiro que quaisquer discursos veiculados na cena sofrem, mesmo sendo extraídos das sociabilidades reais. Mas, sobretudo, em terceiro lugar, é necessário considerar que há uma narrativa veiculada na cena que sobrevêm, ou no mínimo se insinua, à narrativa da matéria real e à narrativa ficcional. Essa é narrativa da constituição da cena como acordo ético, donde opções são feitas,

6 O governo Temer não aparece na peça, mas está absolutamente presente do ponto de vista das formas iguais aos governos militares: ternos, homens, festas. 
seja pelo foco na realidade ou na ficção, seja pela convivência tensionada de ambas, deve ser considerada matéria de excelência do teatro contemporâneo.

Assim sendo, considero da mais alta pertinência uma mirada cuidadosa para as opções tomadas no âmbito dos tensionamentos entre real e ficção, e sigo tentando encontrar modos de criar uma experiência, um estar em situação, um "teatro", que leve à reflexão critica sobre a violência da Guerra Total.

\section{Referências bibliográficas}

BRECHT, B. O declínio do egoísta Johann Fatzer. São Paulo: Cosac \& Naify, 2002. Coletivo Bruto. Vergonha. Set. 2016. (Não publicado.) . O que está aqui é o que sobrou. Jun. 2012. (Não publicado.)

COLETIVO USINA. A sombra de Pinheirinho. Diário Liberdade, 6 fev. 2012. Disponível em: <http://www.diarioliberdade.org/brasil/batalha-de-ideias/24116-a-sombra-do-pinheirinho.html>.

DEBORD, G. A sociedade do espetáculo. Rio de Janeiro: Contraponto, 1997.

DIEGUÉZ, I. Um teatro sem teatro: a teatralidade como campo expandido. Sala Preta, São Paulo, v. 14, n. 1, p. 125-129, 2014.

FINTER, H. A teatralidade e o teatro: espetáculo do real ou realidade do espetáculo? Notas sobre a teatralidade e o teatro recente na Alemanha. Teatro Al Sur, Buenos Aires, n. 25, out 2003. Disponível em: <http://www.rimini-protokoll.de/website/ media/portugiesisch/helga-finter-a-teatralidade-e-o-teatro.pdf $>$.

FISCHER-LICHTE, E. Realidade e ficção no teatro contemporâneo. Sala Preta, São Paulo, v. 13, n. 2, p. 14-32, 2013.

HARTDT, M.; NEGRI, A. Multidão. Rio de Janeiro: Record, 2005.

KATER, F.; SONNE, P. Guerra Cega Simples. nov. 2004. (Não publicado.)

SPIEGUELMAN, A. Maus. São Paulo: Companhia das Letras, 2007.

Recebido em 22/03/2017

Aprovado em 26/04/2017

Publicado em 17/07/2017 